\title{
Epidemiology of chicken anemia virus in Central African Republic and Cameroon
}

\author{
Chantal J Snoeck ${ }^{1 \dagger}$, Giscard F Komoyo ${ }^{2 \dagger}$, Bonya P Mbee ${ }^{3}$, Emmanuel Nakouné ${ }^{2}$, Alain Le Faou ${ }^{4}$, \\ Mbah P Okwen ${ }^{3}$ and Claude P Muller ${ }^{1 *}$
}

\begin{abstract}
Background: Although chicken anemia virus (CAV) has been detected on all continents, little is known about this virus in sub-Saharan Africa. This study aimed to detect and characterize CAV for the first time in Central African Republic and in Cameroon.

Results: An overall flock seroprevalence of 36.7\% was found in Central African Republic during the 2008-2010 period. Virus prevalences were 34.2\% (2008), 14.3\% (2009) and 10.4\% (2010) in Central African Republic and 39\% (2007) and 34.9\% (2009) in Cameroon. CAV DNA was found in cloacal swabs of 76.9\% of seropositive chickens, suggesting that these animals excreted the virus despite antibodies. On the basis of VP1 sequences, most of the strains in Central African Republic and Cameroon belonged to 9 distinct phylogenetic clusters at the nucleotide level and were not intermixed with strains from other continent. Several cases of mixed infections in flocks and individual chickens were identified.

Conclusions: Our results suggest multiple introductions of CAV in each country that later spread and diverged locally. Mixed genotype infections together with the observation of CAV DNA in cloacal samples despite antibodies suggest a suboptimal protection by antibodies or virus persistence.
\end{abstract}

Keywords: Chicken anemia virus, Central African Republic, Cameroon, Antibodies, PCR, Phylogeny, Mixed infection

\section{Background}

Chicken anemia virus (CAV), the only member of the Gyrovirus genus in the Circoviridae family [1], was first discovered in the late 70's [2], but a retrospective study revealed that the virus circulated in chickens long before that [3]. Chickens are considered the only natural host of chicken anemia virus, although anti-CAV antibodies have also been detected in Japanese quails [4] but not in other domestic or wild bird species $[4,5]$. CAV is ubiquitous [6] and the virus seems to be particularly well adapted to its host [7].

The fecal-oral route constitutes probably the main mode of horizontal transmission [8], but CAV was also detected in feather shafts indicating that other modes of dissemination may be possible [9]. Experimental

\footnotetext{
* Correspondence: claude.muller@crp-sante.lu

${ }^{\dagger}$ Equal contributors

'Institute of Immunology, Centre de Recherche Public de la Santé/National Public Health Laboratory, 20A rue Auguste Lumière, L-1950, Luxembourg, Luxembourg

Full list of author information is available at the end of the article
}

infections via the respiratory tract were also successful [10] but the relevance of such experiments in the field is still unclear. The virus can also be transmitted vertically from infected parents, either the male or female $[11,12]$, irrespective of their antibody status $[11,13,14]$, to their progeny. Seroconversion of specific pathogen-free chickens around the onset of lay without detectable virus in the flock suggested that CAV could be maintained in reproductive organs as a latent or persistent infection with low levels of replication, and become reactivated when the animal reaches sexual maturity $[7,11,15]$.

The virus causes severe anemia, pale bone marrow, thymus atrophy and severe immunosuppression in 23 weeks old chickens if they are not protected by maternal antibodies [7]. In older animals infections usually result in subclinical disease that can also lead to economic losses in poultry farms due to reduced weight gain and increased susceptibility to secondary infections [16-19]. Co-infections with Marek's disease virus or infectious bursal disease virus (IBDV) may lead to a more complex and severe disease $[20,21]$. 
Although the poultry sector is an important part of the economy in many African countries, CAV has only been reported without further details from South Africa [22] and more detailed studies were done by us and others in Nigeria [23-27]. In this study, we describe for the first time the presence and the genetic diversity of CAV in Central African Republic (CAF) and in Cameroon (CMR).

\section{Results}

\section{Seroprevalence}

In Bangui (CAF), anti-CAV antibodies were found in 147 chicken sera out of the 400 analyzed. In farms, $36.7 \%(29 / 79)$ of the flocks had at least one chicken with anti-CAV antibodies and there was little change throughout the 3 years of sampling: $34.8 \%(8 / 23)$ in 2008, 39.3\% (11/28) in 2009 and 35.7\% (10/28) in 2010 (Table 1). Four flocks had a seroprevalence below 25\%, 5 flocks had a seroprevalence between 25 and $50 \%$, and 20 flocks had a seroprevalence above 50\% (Table 1). Most seropositive flocks for which the age was available became seropositive after week 5 (Figure 1A). Several farms were visited 2 or 3 times but no trend could be seen when comparing percentage of seropositive animals between collection time points. In the 2 live bird markets where sera were collected, 69\% (68/98) of chickens were seropositive and the seroprevalence in each market was $67.9 \%(38 / 56)$ and $71.4 \%(30 / 42)$.

\section{Virus prevalence}

In CAF, CAV nucleic acids were detected in $45.8 \%$ (11/ 24) of the flocks in 2008, in 31.7\% (19/60) in 2009 and in $15 \%(9 / 60)$ in 2010 (Table 2). Fourteen flocks had a prevalence below 25\%, 7 flocks had a prevalence between 25 and $50 \%$, and 18 flocks had a prevalence above $50 \%$ (Table 2). Similarly to the seroprevalence data, no trend in the percentage of virus infected animals was observed over the time in farms visited several times. CAV was also detected in $21.2 \%(42 / 198)$ of samples collected in live bird markets and 3 of the 5 markets were infected (prevalence of 27.8\% (30/108), 15.5\% (11/71) and 9.1\% (1/11) over 21 months). For 400 animals, sera

Table 1 Seroprevalence in flocks from Central African Republic

\begin{tabular}{ccccccc}
\hline Year & \multicolumn{5}{c}{ Seroprevalence (\%) } & Total \\
\cline { 2 - 6 } & $\mathbf{0}$ & $\mathbf{>} \mathbf{0}$ and $\leq$ & $\mathbf{2 5}$ and $\leq$ & $\mathbf{5 0}$ and $\leq$ & $\mathbf{7 5}$ and $\leq$ & \\
\hline $\mathbf{2 5}$ & 15 & 1 & $\mathbf{5 0}$ & $\mathbf{7 5}$ & $\mathbf{1 0 0}$ & \\
\hline $\mathbf{2 0 0 8}$ & 17 & 1 & 1 & 2 & 4 & 23 \\
$\mathbf{2 0 1 0}$ & 18 & 2 & 3 & 1 & 8 & 28 \\
Total & 50 & 4 & 5 & 6 & 2 & 28 \\
\hline
\end{tabular}

Seroprevalence is expressed as the number of flocks with a seroprevalence included in a percentage range. and swabs were available and $76.9 \%(113 / 147)$ of the antibody positive animals were PCR positive while all antibody negative animals (253/400) were PCR negatives.

Overall prevalences of CAV infections of $34.2 \%$ (26/ 76), $14.3 \%(59 / 412)$ and $10.4 \%(33 / 316)$ were found in 2008, 2009 and 2010 respectively in Central African Republic, compared to 39\% (112/287) in 2007 and 34.9\% (203/582) and 2009 in Cameroon.

In both countries, a total of 433 samples were positive for CAV nucleic acids and were submitted for sequencing.

\section{Phylogenetic analyses of nucleotide sequences}

Sequencing of the VP1 coding region was attempted for all CAV positive samples but only 228 sequences of at least 1281 nucleotides from the 433 positive samples were obtained. The phylogeny of these 228 VP1 gene sequences (1281 bp) revealed several clusters within group II or III in both countries (Figure 2). The 53 VP1 sequences from 20 chicken flocks and 3 live bird markets in Bangui formed 4 groups (CAF1 to CAF4; Figures 2 and 3). CAF1 strains were very similar to each other (maximal Kimura distance mKd 0.5\%) and 1 strain CAF09-144 clustered outside CAF1 group (mKd 0.9\% to CAF1). The CAF1 strains were most closely related to strains from Argentina, 2007-2008 (Figure 3). The CAF2 group consisted of only 2 strains (mKd 2.1\%) that formed an isolated cluster within group II (Figure 3). Twenty-five strains formed the CAF3 group (mKd 0.8\%; Figure 3). The CAF4 group contained 8 strains and was as diverse as CAF2 (mKd 2.1\%), but the clustering of CAF09-153 was uncertain as shown by the discrepancies in the trees of Figures 2 and 3. All groups contained strains from farms and live bird markets, except CAF2 which contained strains from markets only. All strains from 2008 clustered in CAF1 and CAF3; 2009 strains were found in all groups and 2010 strains in CAF1 to 3.

One hundred seventy-five sequences from chickens in Cameroon clustered in 5 main groups (CMR1 to CMR5; Figures 2 and 4). CMR1 cluster included 104 strains from both 2007 and 2009 (mKd 1.4\%), and a Nigerian strain CAV/Ejioku.NIE/11.02/107 (Figure 4A). CMR2 contained 11 strains from 2009 (mKd 0.2\%; Figure 4B) and was most closely related to a Japanese strain and to the CAF3 cluster (Figure 2). The CMR3 group included 35 strains from 2009 (mKd 0.9\%) and was most closely related to a Chinese strain CH_CK/05-01/HN/592 (Figure 4B). In addition, 1 strain CMR09-565.1 clustered outside CMR3 group (mKd to CMR3 of 1.3\%; Figure 2). CMR4 cluster contained 21 very similar strains from 2007 only (mKd $0.2 \%$ ). Two strains from 2009 clustered in CMR5 (mKd 0.1\%; Figure 4B), and one strain (CMR09-314) clustered with Argentinean strains but did not intermingle with CAF1 strains (Figures 2 and 4B). 


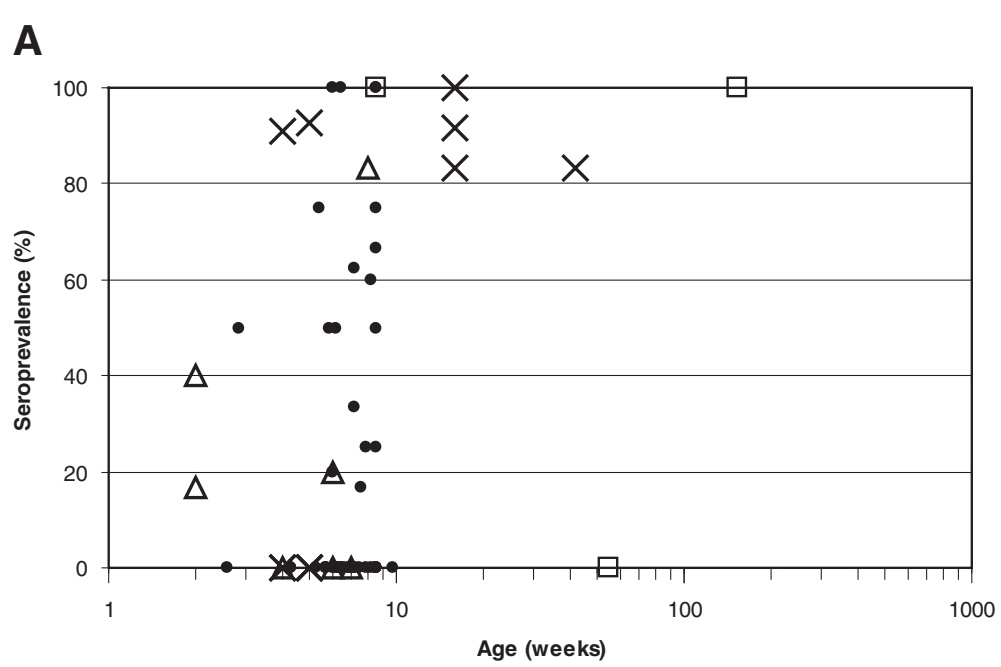

B

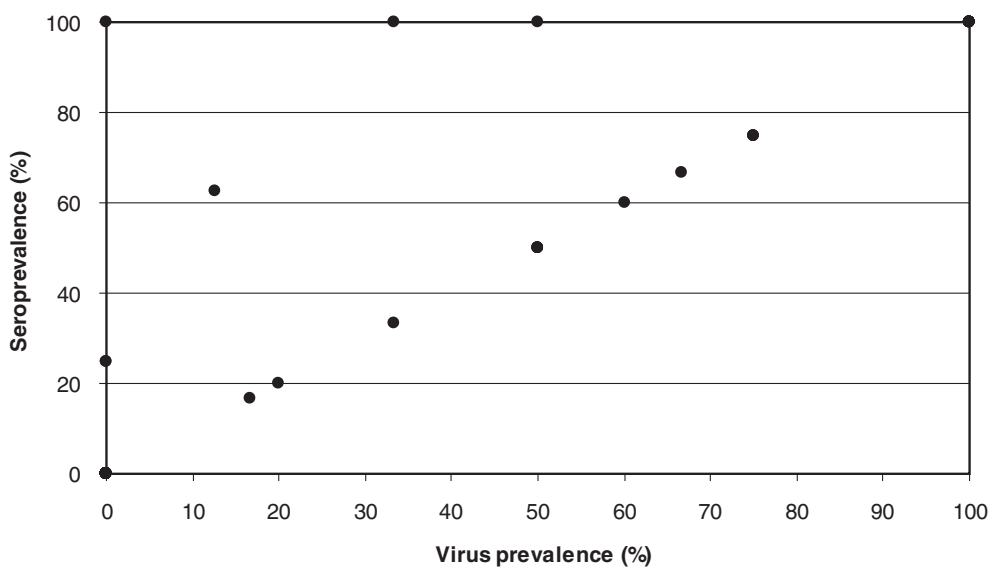

Figure 1 Anti-CAV antibody seroprevalence in CAF. (A) Age-dependent seroprevalence in broiler flocks ( $\bullet$ ) and layer flocks ( $\square$ ) in CAF and in broiler $(\Delta)$ or pullet and layer $(x)$ flocks in Nigeria (from Owoade et al. [27]). (B) Relation between seroprevalence and virus DNA prevalence in chicken flocks in CAF

\section{Mixed infections}

After cloning, sequences of the clones were compared to the original electropherograms of the (uncloned) sample showing signs of mixed infection. The electropherogram of the original sample and the clones matched in all cases, confirming in two independent sequencing experiments

Table 2 Virus prevalence in flocks from Central African Republic

\begin{tabular}{ccccccc}
\hline Year & \multicolumn{5}{c}{ Virus prevalence (\%) } & Total \\
\cline { 2 - 6 } & $\mathbf{0}$ & $\mathbf{>} \mathbf{0}$ and $\leq$ & $\mathbf{2 5}$ and $\leq$ & $\mathbf{5 0}$ and $\leq$ & $\mathbf{7 5}$ and $\leq$ & \\
\hline $\mathbf{2 5}$ & 13 & 2 & $\mathbf{5 0}$ & $\mathbf{7 5}$ & $\mathbf{1 0 0}$ & \\
\hline $\mathbf{2 0 0 8}$ & 41 & 6 & 3 & 3 & 2 & 24 \\
$\mathbf{2 0 1 0}$ & 51 & 6 & 0 & 4 & 6 & 60 \\
Total & 105 & 14 & 7 & 8 & 2 & 60 \\
\hline
\end{tabular}

Virus prevalence is expressed as the number of flocks with a virus prevalence included in a percentage range. that the mixed infections were not due to contamination during the amplification steps.

In Central African Republic, 6 flocks out of 20 from which CAV sequences were obtained, contained strains of 2 different genotypes (Table 3), either CAF1 and CAF3, or CAF1 and CAF4 strains. CAF1 and CAF4 strains were also both found in 2 markets. In addition, analyses of VP1 clones from samples with ambiguous nucleotides revealed mixed infections in 6 individual samples with the above combinations of genotypes (CAF1 and CAF3, CAF1 and CAF4) as well as CAF2 and CAF3 (Figure 3). In 3 of these cases, both parental strains were also found in other samples from the same farm or market (Table 3).

Similarly, CAV VP1 sequences in 13 samples from Cameroon out of 35 showing ambiguous nucleotides were cloned. Analyses of clones showed that these samples contained more than one CAV genotype, 
Figure 2 Phylogenetic analysis of partial VP1 sequences (1281 nucleotides) of 228 CAV strains from Central African Republic $(\bullet)$ and Cameroon $(\boldsymbol{\Lambda})$. Sequences from mixed infected samples are represented by the grey symbols. CAF and CMR clusters are shown as aggregated clusters (CAF1-CAF4; CMR1-CMR5). Only bootstrap values higher than $50 \%$ are shown.
AM407827 CH

AM407827 CH_CK/05-05/GD/5258 / China 57 - HQ872034 JS-78 / China

¿ AM407817 CH_CK/05-01/GD/210 / China DQ124935 AH6/China

4 CMR5

100 AJ888527 CAV/Lagos.NIE/11.02/38 / Nigeria

AJ888528 CAV/Lanlate.NIE/11.02/71 / Nigeria

DQ016138 130 / Slovenia

7- AJ888524 CAV/Abeokuta.NIE/19.04/118 / Nigeria 53 - AF395114 BD-3/Bengladesh

52 \% DQ16139469 / Slovenia

DQ016140 69 / Slovenia

AY583756 CAV-B/Chicken / India

AJ888525 CAV/Abeokuta.NIE/19.04/117 / Nigeria ${ }_{99}$ CMR4

-HM018724 09Q227 / South Korea

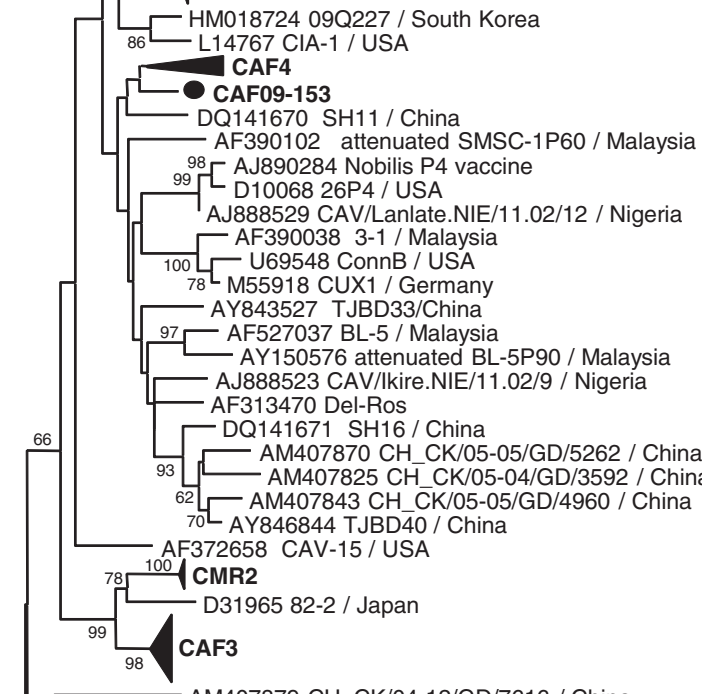

43

AM407879 CH CK/04-12/GD/7616 / China

U69549 L-028 / USA

CAF2

93 CAF1

55 EU871782 Arg753 / Argentina

EU871767 Arg439 / Argentina

64 - $\triangle$ CMR09-314

EU871770 Arg609 / Argentina

- EU871773 Arg513 / Argentina

90 [8 E E71779 ArgA0018R / Argentina

— EU871776 Arg684 / Argentina

5 EU871780 ArgA0010_28 / Argentina

AB027470 TR20

AF285882 SMSC-1 / Malaysia

99 - AM407851 CH_SCK/04-05/GD/3450 / China AF311900 98D06073 / USA

/ 3 - AJ888521 CAV/Ibadan.NIE/14.04/116 / Nigeria

- DQ124936 AH4 / China

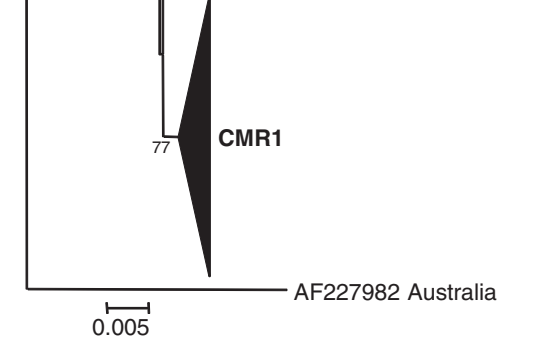




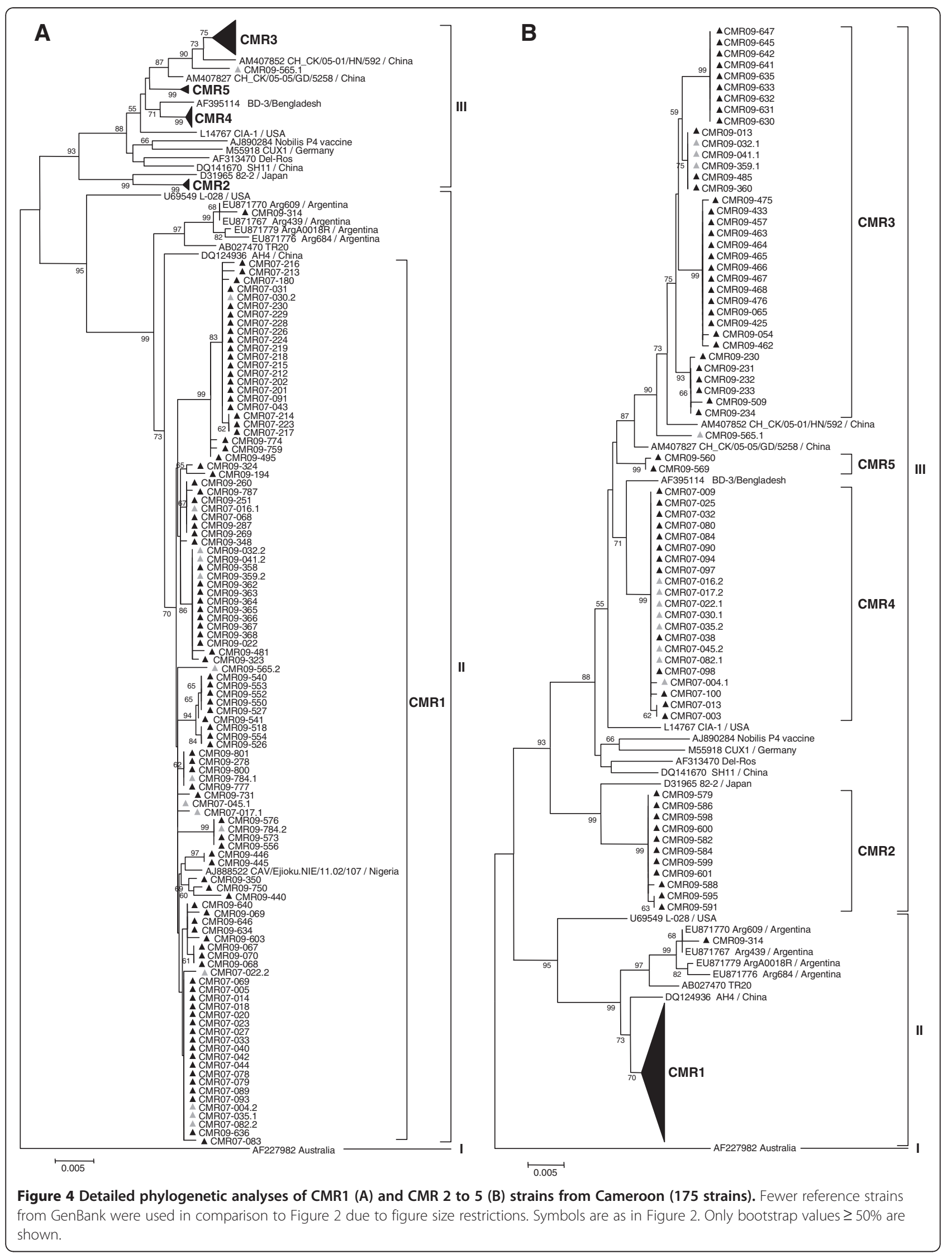


Table 3 Mixed infections in flocks, markets and in individual samples from Central African Republic

\begin{tabular}{|c|c|c|}
\hline Flock & Sample & Clusters \\
\hline \multirow[t]{2}{*}{ Flock 1} & CAF08-044 & CAF1 + CAF3 \\
\hline & CAF08-045 & CAF1 \\
\hline \multirow[t]{4}{*}{ Flock 2} & CAF08-068 & CAF1 \\
\hline & CAF08-069 & CAF3 \\
\hline & CAF08-070 & CAF3 \\
\hline & CAF08-071 & CAF3 \\
\hline \multirow[t]{3}{*}{ Flock 3} & CAF08-072 & CAF1 \\
\hline & CAF08-074 & CAF3 \\
\hline & CAF08-075 & CAF3 \\
\hline \multirow[t]{3}{*}{ Flock 4} & CAF08-076 & CAF1 + CAF3 \\
\hline & CAF08-078 & CAF1 + CAF3 \\
\hline & CAF08-079 & CAF1 \\
\hline \multirow[t]{2}{*}{ Flock 5} & CAF09-131 & CAF4 \\
\hline & CAF09-132 & CAF1 \\
\hline \multirow[t]{4}{*}{ Flock 6} & CAF09-144 & - \\
\hline & CAF09-145 & CAF1 \\
\hline & CAF09-146 & CAF1 + CAF3 \\
\hline & CAF09-147 & CAF3 \\
\hline \multirow[t]{4}{*}{ Market 1} & CAF09-119 & CAF1 + CAF4 \\
\hline & CAF09-116 & CAF4 \\
\hline & CAF09-117 & CAF4 \\
\hline & CAF09-118 & CAF1 \\
\hline \multirow[t]{2}{*}{ Market 2} & CAF09-142 & CAF1 \\
\hline & CAF09-143 & CAF4 \\
\hline Market 3 & CAF09-148 & $\mathrm{CAF} 2+\mathrm{CAF} 3$ \\
\hline
\end{tabular}

suggesting mixed infections in 2007 with CMR1 and CMR4 and in 2009 with CMR1 and CMR3 strains or with 2 distinct CMR1 strains (CMR09-784.1 and CMR09-784.2) differing by 7 nucleotides (Figure 4).

\section{Phylogenetic analyses of amino acid sequences}

At the amino acid level, the groups I to III defined at the nucleotide level were less clearly distinguishable (Figure 5). Nevertheless most of the CAF/CMR strains still clustered with sequences of their own nucleotide sequence group sharing specific amino acid sequences (Table 4), except for CMR09-440 (CMR1) and CMR09630 (CMR3), both of which clustered together with an Argentinian strain (ArgA0010_28), as a result of Q139K and Q144E mutations located in the hypervariable region. CAF2 and CAF4 sequences, CAF3 and CMR2, and CMR3 and CMR5 sequences were identical at the amino acid level as a result of synonymous mutations (Table 4). All CAF/CMR clusters shared amino acids with published

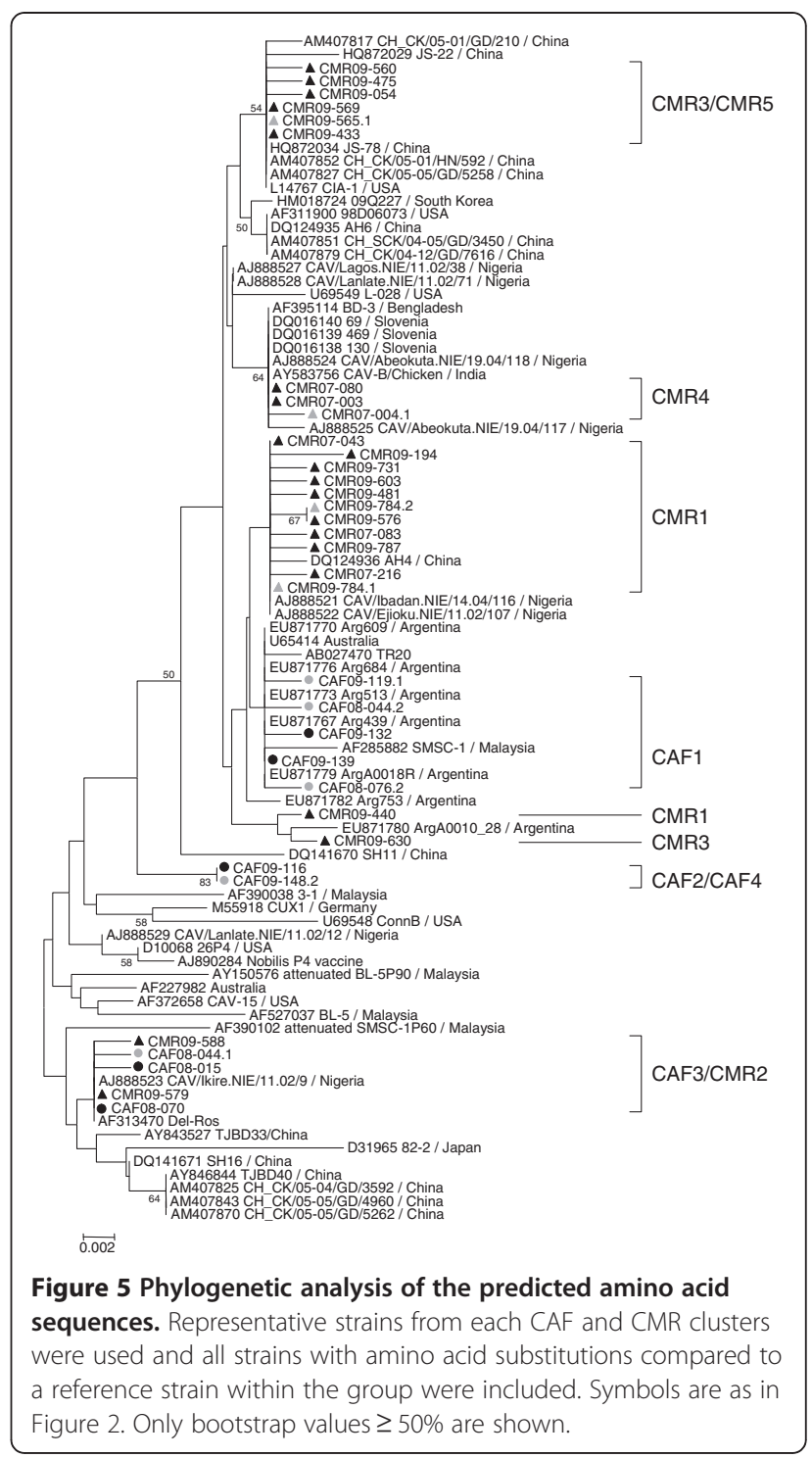

sequences except the CAF2/CAF4 group that had a unique amino acid pattern (Table 4, Figure 5).

Sixteen unique amino acid substitutions were observed in the strains from Central African Republic and Cameroon (R6L, R9K, F77L, G74E, S178P, G219E, S229Y, I285V, S300N, M311I, K341R, Q351H, T361A, D366E,

Table 4 Amino acid patterns in VP1 protein of the African genomic groups

\begin{tabular}{lccccccccc}
\hline \multicolumn{1}{c}{ Cluster } & $\mathbf{2 2}$ & $\mathbf{7 5}$ & $\mathbf{9 7}$ & $\mathbf{1 3 9}$ & $\mathbf{1 4 4}$ & $\mathbf{2 8 7}$ & $\mathbf{2 9 0}$ & $\mathbf{3 7 0}$ & $\mathbf{4 1 3}$ \\
\hline CAF1 & $\mathrm{H}$ & $\mathrm{I}$ & $\mathrm{L}$ & $\mathrm{Q}$ & $\mathrm{Q}$ & $\mathrm{T}$ & $\mathrm{P}$ & $\mathrm{S}$ & $\mathrm{A}$ \\
CAF2/CAF4 & $\mathrm{H}$ & $\mathrm{V}$ & $\mathrm{M}$ & $\mathrm{Q}$ & $\mathrm{Q}$ & $\mathrm{S}$ & $\mathrm{A}$ & $\mathrm{G}$ & $\mathrm{S}$ \\
CAF3/CMR2 & $\mathrm{H}$ & $\mathrm{V}$ & $\mathrm{M}$ & $\mathrm{K}$ & $\mathrm{E}$ & $\mathrm{S}$ & $\mathrm{A}$ & $\mathrm{G}$ & $\mathrm{S}$ \\
CMR1 & $\mathrm{H}$ & $\mathrm{I}$ & $\mathrm{L}$ & $\mathrm{Q} / \mathrm{K}$ & $\mathrm{Q} / \mathrm{E}$ & $\mathrm{T}$ & $\mathrm{A}$ & $\mathrm{S}$ & $\mathrm{A}$ \\
CMR3/CMR5 & $\mathrm{N}$ & $\mathrm{I}$ & $\mathrm{L}$ & $\mathrm{Q} / \mathrm{K}$ & $\mathrm{Q} / \mathrm{E}$ & $\mathrm{A}$ & $\mathrm{A}$ & $\mathrm{S}$ & $\mathrm{A}$ \\
CMR4 & $\mathrm{H}$ & $\mathrm{I}$ & $\mathrm{L}$ & $\mathrm{Q}$ & $\mathrm{Q}$ & $\mathrm{A}$ & $\mathrm{A}$ & $\mathrm{T}$ & $\mathrm{A}$ \\
\hline
\end{tabular}


G398D, G426S) and 3 substitutions were found in 3 to 6 strains (L190M, T215A, V385I).

\section{Discussion}

The overall flock seroprevalence of $36.7 \%$ in CAF appeared to be lower than in most other developing countries. In Nigeria, the only African country from where such data are available, a flock seroprevalence of $55 \%$ was reported in 20 flocks including broilers, pullets, cockerels and layers in the main hub of the poultry industry in the Southwest of the country [27]. Even a seroprevalence of $89 \%$ was reported later in chicken flocks of 4 to 12 months of age [24]. Also countries such as China [28], Malaysia [29], Japan [4], India [30] and Hungary [31] reported flock seroprevalences ranging from 66 to $100 \%$. Normally the seroconversion is not homogeneous within a flock and tends to increase with age, complicating comparisons between studies [5,32]. For instance broiler flocks of 3 to 10 weeks have a similar seroprevalence in Nigeria (40\%) [27] and in CAF (34\%) and the seroprevalence in the flocks ranges from 20 to $100 \%$ in both countries (Figure 1A).

As in Nigeria, chickens are not vaccinated against CAV in Central African Republic. All sampled flocks except 2, were older than 2 to 3 weeks, the age at which the maternal antibodies wane $[5,19,33]$. Thus the antibodies detected are likely the result of a field infection and are not maternally derived nor vaccine induced antibodies.

Similar overall virus prevalences were found in 2007 and 2009 in Cameroon (39\% and 34.9\%) and in 2008 in Central African Republic (34.2\%). In 2009 and 2010, the prevalence decreased to $14.3 \%$ and $10.4 \%$ in Central African Republic. This trend to lower incidence rates in Central African Republic may correspond to an improved sensitivity to hygiene due to farmer awareness in the aftermath of the first results of the study. The above values were also surprisingly low compared to other countries such as China (87\%) [34], Malaysia (80\%) [29] and Argentina (49\%) [35] but comparable to Nigeria (41\%) [23] for the 2007-2008 period. Although the prevalence may vary with time, this may indicate that the virus is less prevalent in sub-Saharan Africa than in Asia or South America. Nevertheless, prevalence rates of viral nucleic acids and antibodies may be underestimated in particular when the prevalence is low in a flock and/or low numbers of chickens were analyzed per flock. For instance, by analyzing 4 samples per flock, the certainty of detecting antigens or antibodies in a infected flock decreases from $93 \%$ when the prevalence is $50 \%$, to $68 \%$ when the prevalence is $25 \%$. A lower expected virus prevalence in the digestive tract compared to lymphoid organs [29], the relative young age of the animals, and possibly co-infections with other pathogens may also contribute to underestimate prevalence rates.

CAV DNA could be detected in cloacal samples of a large majority $(76.9 \%)$ of the seropositive chickens, indicating that these animals may shed the virus despite antibodies (Figure 1B). While antibodies normally develop within 1 to 3 weeks $[6,8,12,36]$, viral particles can be detected in feces up to 5 to 7 weeks post infection $[8,12]$ suggesting that the virus is cleared with considerable delay after the development of virus-neutralizing antibodies. If we assume that most chickens become infected early after the waning of maternal antibodies, persistence of virus may even be longer. This could explain the high prevalence of virus in seroconverted animals. Alternatively co-infections with very virulent IBDV, which is also circulating in West and Central Africa [37-39], may cause a delay in development of anti-CAV antibodies, resulting in CAV persistence and a prolonged viral shedding in feces [20]. Besides the detection of a second round of viral infection cannot be ruled out although the expected excretion period would be short [12].

Although there is no clear geographic clustering of CAV strains worldwide and despite the low mutation rate at the amino acid level [21], most of the strains sequenced in CAF and CMR belonged to 9 distinct clusters at the nucleotide level and were not intermixed with strains from other continent. This suggests multiple introductions of CAV in Central Africa resulting in several clusters that emerged locally and had time to spread and diverge. Normally, chicks used to populate commercial farms in CAF are imported from Europe, but European strains (Germany, Slovenia) available in GenBank are phylogenetically not the closest relatives.

In our study, 6 flocks contained more than 1 CAV strain and 19 samples revealed mixed infections as confirmed by cloning. Similarly, cloning of VP1 sequences from Nigeria [23] and the USA [40] revealed the presence of 2 different strains (belonging to groups II and III) in the same sample. Sequences exhibiting ambiguous nucleotides have also been found in China [34] and Brazil [41] but these were not further investigated. Thus, mixed infection by CAV strains may be a relatively common event, but its impact is currently unknown.

\section{Conclusions}

Despite the low (sero) prevalence found in Central African Republic and Cameroon compared to other countries, several clusters including only African strains were found. This suggests multiple introductions of CAV that spread and diverged locally. Mixed genotype infections together with the observation of CAV DNA in cloacal samples despite antibodies suggest a suboptimal protection by antibodies or virus persistence. 


\section{Methods}

\section{Sample cohorts}

In the framework of enhanced laboratory surveillance for avian viruses in the aftermath of avian influenza outbreaks in West and Central Africa, an average of 4 (between 1 and 16) cloacal samples per flock (broilers or layers) in 5 randomly selected farms were collected every month between June 2008 and December $2010(n=606)$ in Bangui (CAF). Cloacal swabs $(n=198)$ were also collected in two live bird markets every month between April 2009 and December 2010. In addition, 400 sera from swabbed birds were collected. Whenever recorded (in $73 \%$ of the flocks), the age of the animals ranged from 18 to 68 days for broiler flocks and from 8 weeks to 3 years for layer flocks.

In Cameroon, 287 cloacal swabs and 582 pooled tracheal-cloacal swabs from chicken were collected in 2007 (January to June) and 2009 (April to June) respectively in farms only (2007) or in farms and live bird markets (2009) within a $50 \mathrm{~km}$ radius around the town of Bamenda, North West Region. The age of the animals was not recorded.

\section{Enzyme-linked immunosorbent assay (ELISA)}

A commercial competitive ELISA kit (FlockCheck ${ }^{\circledR}$ CAV, IDEXX, Hoofddorp, The Netherlands) was used to detect specific antibodies against CAV in chicken sera $(n=400)$ at a 1:10 dilution. Sera samples were collected from birds in farms $(n=302)$ and live bird markets $(n=98)$. Optical density was measured using a Multiskan Ascent reader (Thermo Labsystems, Helsinki, Finland) at $650 \mathrm{~nm}$. Sample to negative $(\mathrm{S} / \mathrm{N})$ ratios were calculated for each sample and samples with $\mathrm{S} / \mathrm{N}$ ratios $\leq 0.60$ were considered positive.

\section{Nucleic acid extraction, polymerase chain reactions}

All swabs were discharged in $500 \mu \mathrm{l}$ of virus transport medium (VTM) containing $2000 \mathrm{U} / \mathrm{ml}$ penicillin, $200 \mathrm{mg} / \mathrm{ml}$ streptomycin, $2000 \mathrm{U} / \mathrm{ml}$ polymyxin B, $250 \mathrm{mg} / \mathrm{ml}$ gentamycin, $60 \mathrm{mg} / \mathrm{ml}$ ofloxacin, $200 \mathrm{mg} / \mathrm{ml}$ sulfamethoxazole and $2.5 \mathrm{mg} / \mathrm{ml}$ amphotericin $\mathrm{B}$. Nucleic acids were extracted from $140 \mu \mathrm{l}$ of VTM using QIAamp Viral RNA Mini Kit (Qiagen, Venlo, The Netherlands). Extracted nucleic acids were screened for CAV DNA in a nested PCR format using previously published primers [11]. The equivalent of $2.5 \mu \mathrm{l}$ of nucleic acids and $0.5 \mu \mathrm{l}$ of first round PCR products were used in the first round and nested PCRs respectively. PCR reactions were carried out using the following cycling conditions: initial denaturation at $95^{\circ} \mathrm{C}$ for $5 \mathrm{~min}$, 40 cycles of amplification at $95^{\circ} \mathrm{C}$ for $30 \mathrm{~s}, 54^{\circ} \mathrm{C}\left(1^{\text {st }}\right.$ round) or $60^{\circ} \mathrm{C}$ (nested) for $30 \mathrm{~s}, 72^{\circ} \mathrm{C}$ for $1 \mathrm{~min}$, and a final extension at $72^{\circ} \mathrm{C}$ for $10 \mathrm{~min}$. PCR products were visualized by gel electrophoresis.
The certainty $C$ of detecting CAV in an infected flock for various flock sizes $N$ and various prevalences $P$ was calculated according to the formula of Cannon and Roe (1982, cited by [42]): $n=\left\{1-(1-\mathrm{C})^{1 / \text { PxNxsens }}\right\}$ $\{\mathrm{N}-0.5(\mathrm{PxN}-1)\}$ assuming an average number of $n=4$ samples collected per flock and a test sensitivity (sens) of $100 \%$.

\section{Sequencing}

A fragment containing the entire VP1 coding region (nucleotides 1 to 1350) of the positive samples was amplified as 3 partially overlapping fragments with a total length of 1389 bp (from nucleotide -33 to nucleotide 1355) using several primer combinations [23]. Sequencing of purified PCR products was performed as previously described [34]. Sequence assembly and analyses were performed using SeqScape version 2.5 (Applied Biosystems, Nieuwerkerk, The Netherlands) and BioEdit [43]. The 5' end of the VP1 coding region (69 nucleotides) was not reliably sequenced for a few strains. Therefore a shorter fragment (1281 nucleotides) was used in the phylogenetic analyses in order to include as many strains as possible.

\section{Cloning}

Samples exhibiting ambiguous determination of nucleotides at various positions caused by clear double peaks in the electropherogram were further analyzed. The VP1 fragments of 1370 bp were generated starting from the original DNA sample using primers OS1F and S3R7 ( $1^{\text {st }}$ round PCR; nucleotides -117 to 1355$)$ and S1F and S3R1 (5'-CCCAGTACATSGTGCTGTT-3') primers (nested PCR; nucleotides -33 to 1336), purified and cloned using the TOPO TA cloning kit (Life Technologies, Merelbeke, Belgium) as described previously [23]. Ten to 24 colonies were selected and inserts were sequenced with M13 primers (Life Technologies). To exclude the possibility of crosscontamination, long amplicons (1370 bp) suitable for cloning were generated twice in two independent experiments (on different days) and were cloned separately (again on different days) for two samples and similar results were obtained. Both experiments gave clones of the same sequences although with different frequencies.

\section{Phylogenetic analyses}

Genetic distances were calculated with MEGA v5.03 [44] according to the Kimura 2-parameters model. Phylogenetic relationships were inferred by comparing the African strains with all CAV DNA sequences available on GenBank (downloaded in February 2012) after removal of short sequences and sequences with insertions or deletions resulting in frame shifts. Datasets were aligned using ClustalW [45]. Trees were calculated with the NeighbourJoining method, using the Kimura 2-parameters model and 
1000 bootstrap replicates for the nucleotide tree and with the Poisson model for the amino acid tree (MEGA v5.03; data not shown). Reference strains from GenBank were selected based on these preliminary analyses. Trees including the selected reference strains from GenBank and all (Figure 2) or a subset (Figure 5) of the sequences generated in this study were calculated using the same parameters as described above. Fewer representative strains from GenBank were used in Figures 3 and 4 due to figure size restrictions. All gene sequences can be found under accession numbers [EMBL: HE662876 to HE663056 and HE686970 to HE687016]. Strains were designated using the following nomenclature: 3-letter country code $(\mathrm{CAF}=$ Central African Republic; CMR = Cameroon)_year-sample number (last 3 digits). Sequences from mixed infected samples are named by adding .1 or .2 after the strain name.

\section{Abbreviations}

bp: Base pair(s); CAF: Central African Republic; CAV: Chicken anemia virus; CMR: Cameroon; ELISA: Enzyme-linked immunosorbent assay; IBDV: Infectious bursal disease virus; mKd: Maximal Kimura distance; PCR: Polymerase chain reaction; S/N: Sample to negative; VP1: Viral protein 1; VTM: Virus transport medium.

\section{Competing interests}

The authors declare that they have no competing interests.

\section{Author's contributions}

CJS, EN, MPO, AL and CPM designed the study. CJS, GFK and BPM carried out the experiments and analyzed the results. CJS drafted the manuscript and $\mathrm{AL}, \mathrm{EN}, \mathrm{MPO}$ and CPM contributed to the discussion and reviewed the manuscript. All authors read and approved the final manuscript.

\section{Acknowledgements}

The authors wish to thank A. Sausy, E. Charpentier and R. Brunnhöfer for technical help and T.E. Fon of Science for Life Foundation for help in sample collection in Cameroon. They also acknowledge the Ministry of Agriculture of Central African Republic and the Agence Nationale pour le Développement de l'Elevage, particularly Dr Marie-Noël Mbaikoua, for technical support and the US Department of Health and Human Services for their financial support. They gratefully acknowledge the Ministry of Cooperation of Luxembourg, the Ministry of Health, the Ministry of Research and the Centre de Recherche Public de la Santé for their generous financial and moral support. C.J.S. was supported by an AFR fellowship TR_PHD BFR08-095 from the Fonds National de la Recherche, Luxembourg.

\section{Author details}

${ }^{1}$ Institute of Immunology, Centre de Recherche Public de la Santé/National Public Health Laboratory, 20A rue Auguste Lumière, L-1950, Luxembourg, Luxembourg. ${ }^{2}$ Institut Pasteur de Bangui, Bangui, Central African Republic. ${ }^{3}$ District Hospital Bali, North West Regional Delegation of Public Health, Bamenda, Cameroon. 'Laboratoire de Virologie Hôpital de Brabois Adultes, CHU de Nancy, 54511, Vandoeuvre-lès-Nancy, France.

Received: 6 October 2011 Accepted: 14 August 2012

Published: 8 September 2012

\section{References}

1. Virus taxonomy: release. 2009. http://ictvonline.org/virusTaxonomy.asp? version=2009.

2. Yuasa N, Taniguchi T, Yoshida I: Isolation and some characteristics of an agent inducing anemia in chicks. Avian Dis 1979, 23:366-385.

3. Toro H, Ewald S, Hoerr FJ: Serological evidence of chicken infectious anemia virus in the United States at least since 1959. Avian Dis 2006, 50:124-126.
4. Farkas T, Maeda K, Sugiura H, Kai K, Hirai K, Otsuki K, Hayashi T: A serological survey of chickens, Japanese quail, pigeons, ducks and crows for antibodies to chicken anaemia virus (CAV) in Japan. Avian Pathol 1998, 27:316-320

5. McNulty MS, Connor TJ, McNeilly F, Kirkpatrick KS, McFerran JB: A serological survey of domestic poultry in the United Kingdom for antibody to chicken anaemia agent. Avian Pathol 1988, 17:315-324.

6. Schat KA: Chicken Infectious Anemia. In Diseases of Poultry. 11th edition. Edited by Saif YM, Barnes HJ, Glisson JR, Fadly AM, McDougald LR, Swayne DE. Ames, lowa: lowa State University Press; 2003:182-202.

7. Miller MM, Schat KA: Chicken infectious anemia virus: an example of the ultimate host-parasite relationship. Avian Dis 2004, 48:734-745.

8. Yuasa N, Taniguchi T, Imada T, Hihara H: Distribution of chicken anemia agent (CAA) and detection of neutralizing antibody in chicks experimentally inoculated with CAA. Natl Inst Anim Health Q (Tokyo) 1983, 23:78-81.

9. Davidson I, Artzi N, Shkoda I, Lublin A, Loeb E, Schat KA: The contribution of feathers in the spread of chicken anemia virus. Virus Res 2008 , 132:152-159.

10. Rosenberger JK, Cloud SS: The effects of age, route of exposure, and coinfection with infectious bursal disease virus on the pathogenicity and transmissibility of chicken anemia agent (CAA). Avian Dis 1989, 33:753-759.

11. Cardona CJ, Oswald WB, Schat KA: Distribution of chicken anaemia virus in the reproductive tissues of specific-pathogen-free chickens. J Gen Virol 2000, 81:2067-2075.

12. Hoop RK: Persistence and vertical transmission of chicken anaemia agent in experimentally infected laying hens. Avian Pathol 1992, 21:v493-501.

13. Brentano L, Lazzarin S, Bassi SS, Klein TA, Schat KA: Detection of chicken anemia virus in the gonads and in the progeny of broiler breeder hens with high neutralizing antibody titers. Vet Microbiol 2005, 105:65-72.

14. Miller MM, Ealey KA, Oswald WB, Schat KA: Detection of chicken anemia virus DNA in embryonal tissues and eggshell membranes. Avian Dis 2003, 47:662-671.

15. Miller MM, Jarosinski KW, Schat KA: Negative modulation of the chicken infectious anemia virus promoter by COUP-TF1 and an E box-like element at the transcription start site binding deltaEF1. J Gen Virol 2008 89:2998-3003.

16. Davidson I, Kedem M, Borochovitz H, Kass N, Ayali G, Hamzani E, Perelman B, Smith B, Perk S: Chicken infectious anemia virus infection in Israeli commercial flocks: virus amplification, clinical signs, performance, and antibody status. Avian Dis 2004, 48:108-118.

17. Mcllroy SG, McNulty MS, Bruce DW, Smyth JA, Goodall EA, Alcorn MJ: Economic effects of clinical chicken anemia agent infection on profitable broiler production. Avian Dis 1992, 36:566-574.

18. McNulty MS, Mcllroy SG, Bruce DW, Todd D: Economic effects of subclinical chicken anemia agent infection in broiler chickens. Avian Dis 1991, 35:263-268.

19. Sommer F, Cardona C: Chicken anemia virus in broilers: dynamics of the infection in two commercial broiler flocks. Avian Dis 2003, 47:1466-1473.

20. Imai K, Mase M, Tsukamoto K, Hihara H, Yuasa N: Persistent infection with chicken anaemia virus and some effects of highly virulent infectious bursal disease virus infection on its persistency. Res Vet Sci 1999, 67:233-238

21. Schat KA: Chicken anemia virus. Curr Top Microbiol Immunol 2009, 331:151-183.

22. Wicht JD, Maharaj SB: Chicken anaemia agent in South Africa. Vet Rec 1993, 133:147-148

23. Ducatez MF, Owoade AA, Abiola JO, Muller CP: Molecular epidemiology of chicken anemia virus in Nigeria. Arch Virol 2006, 151:97-111.

24. Emikpe BO, Oluwayelu DO, Ohore OG, Oladele OA, Oladokun AT: Serological evidence of chicken anaemia virus infection in Nigerian indigenous chickens. Onderstepoort J Vet Res 2005, 72:101-103.

25. Oluwayelu DO, Todd D, Ball NW, Scott AN, Oladele OA, Emikpe BO, Fagbohun OA, Owoade AA, Olaleye OD: Isolation and preliminary characterization of chicken anemia virus from chickens in Nigeria. Avian Dis 2005, 49:446-450.

26. Oluwayelu DO, Todd D, Olaleye OD: Sequence and phylogenetic analysis of chicken anaemia virus obtained from backyard and commercial chickens in Nigeria. Onderstepoort J Vet Res 2008, 75:353-357. 
27. Owoade AA, Oluwayelu DO, Fagbohun OA, Ammerlaan W, Mulders MN, Muller CP: Serologic evidence of chicken infectious anemia in commercial chicken flocks in southwest Nigeria. Avian Dis 2004, 48:202-205.

28. Zhou W, Yang B, Shen B, Han S, Zhou J: A serologic survey of antibody against chicken infectious anemia virus by indirect immunofluorescent assay in domestic poultry in China. Avian Dis 1996, 40:358-360.

29. Hailemariam Z, Omar AR, Hair-Bejo M, Giap TC: Detection and characterization of chicken anemia virus from commercial broiler breeder chickens. Virol J 2008, 5:128.

30. Bhatt P, Shukla SK, Mahendran M, Dhama K, Chawak MM, Kataria JM: Prevalence of Chicken Infectious Anaemia Virus (CIAV) in commercial poultry flocks of Northern India: a serological survey. Transbound Emerg Dis 2011, 58:458-460.

31. Dren C, Farkas T, Nemeth I: Serological survey on the prevalence of chicken anaemia virus infection in Hungarian chicken flocks. Vet Microbiol 1996, 50:7-16

32. De Herdt P, Van den Bosch G, Ducatelle R, Uyttebroek E, Schrier C: Epidemiology and significance of chicken infectious anemia virus infections in broilers and broiler parents under nonvaccinated European circumstances. Avian Dis 2001, 45:706-708.

33. Otaki Y, Saito K, Tajima M, Nomura Y: Persistence of maternal antibody to chicken anaemia agent and its effect on the susceptibility of young chickens. Avian Pathol 1992, 21:147-151.

34. Ducatez MF, Chen H, Guan Y, Muller CP: Molecular epidemiology of chicken anemia virus (CAV) in southeastern Chinese live birds markets. Avian Dis 2008, 52:68-73.

35. Craig Ml, Rimondi A, Delamer M, Sansalone P, Konig G, Vagnozzi A, Pereda A: Molecular characterization of chicken infectious anemia virus circulating in Argentina during 2007. Avian Dis 2009, 53:331-335.

36. van Santen VL, Joiner KS, Murray C, Petrenko N, Hoerr FJ, Toro H: Pathogenesis of chicken anemia virus: comparison of the oral and the intramuscular routes of infection. Avian Dis 2004, 48:494-504.

37. Courtecuisse C, Japiot F, Bloch N, Diallo I: Serological survey on newcastle and gumboro diseases, pasteurellosis and pullorosis in local hens in Niger. Rev Elev Med Vet Pays Trop 1990, 43:27-29.

38. Durojaiye OA, Kwenkam P: A preliminary note on the prevalence of infectious bursal disease of poultry in Cameroon. Rev Elev Med Vet Pays Trop 1990, 43:439-440.

39. Owoade AA, Mulders MN, Kohnen J, Ammerlaan W, Muller CP: High sequence diversity in infectious bursal disease virus serotype 1 in poultry and turkey suggests West-African origin of very virulent strains. Arch Virol 2004, 149:653-672.

40. van Santen VL, Li L, Hoerr FJ, Lauerman LH: Genetic characterization of chicken anemia virus from commercial broiler chickens in Alabama. Avian Dis 2001, 45:373-388.

41. Simionatto S, Lima-Rosa CA, Binneck E, Ravazzolo AP, Canal CW: Characterization and phylogenetic analysis of Brazilian chicken anaemia virus. Virus Genes 2006, 33:5-10.

42. De Wit JJ: Detection of infectious bronchitis virus. Avian Pathol 2000, 29:71-93.

43. Hall TA: BioEdit: a user-friendly biological sequence alignment editor and analysis program for Windows 95/98/NT. Nucleic Acids Symp Ser 1999, 41:95-98.

44. Tamura K, Peterson D, Peterson N, Stecher G, Nei M, Kumar S: MEGA5: molecular evolutionary genetics analysis using maximum likelihood, evolutionary distance, and maximum parsimony methods. Mol Biol Evol 2011, 28:2731-2739.

45. Thompson JD, Higgins DG, Gibson TJ: CLUSTAL W: improving the sensitivity of progressive multiple sequence alignment through sequence weighting, position-specific gap penalties and weight matrix choice. Nucleic Acids Res 1994, 22:4673-4680.

doi:10.1186/1743-422X-9-189

Cite this article as: Snoeck et al: Epidemiology of chicken anemia virus in Central African Republic and Cameroon. Virology Journal 2012 9:189.

\section{Submit your next manuscript to BioMed Central and take full advantage of:}

- Convenient online submission

- Thorough peer review

- No space constraints or color figure charges

- Immediate publication on acceptance

- Inclusion in PubMed, CAS, Scopus and Google Scholar

- Research which is freely available for redistribution

Submit your manuscript at www.biomedcentral.com/submit 